\title{
Il mattone cuneiforme maiolicato. Procedure algoritmico-parametriche digitali come strumento di indagine e progettazione: dall'architettura storica all'innovazione del design
}

\author{
Francesco Di Paola \\ Giovanni Fatta \\ Calogero Vinci
}

Abstract

II presente studio si concentra sul mattone cuneiforme in laterizio maiolicato diffusosi in Sicilia a partire dal XVI secolo per la realizzazione di cuspidi e cupole. Un elemento unificante che ha costituito un particolare apporto identitario alla tradizione laterizia isolana; una soluzione originale in grado di coniugare l'istanza estetica con quella strutturale e di durabilità. Si descrivono, sulla scorta di più di un centinaio di casi esaminati, le differenti peculiarità geometrico-formali riscontrate in relazione alle caratteristiche dell'involucro.

Si riportano alcuni approfondimenti di analisi e di controllo dei tradizionali pattern geometrici compositivi del paramento murario. Attraverso la definizione di strumenti digitali di progettazione algoritmico-parametrica, si propongono nuove configurazioni di tessitura muraria su superfici a curvatura variabile per una contemporanea riproposizione dell'elemento costruttivo con materiali e tecniche di ultima generazione.
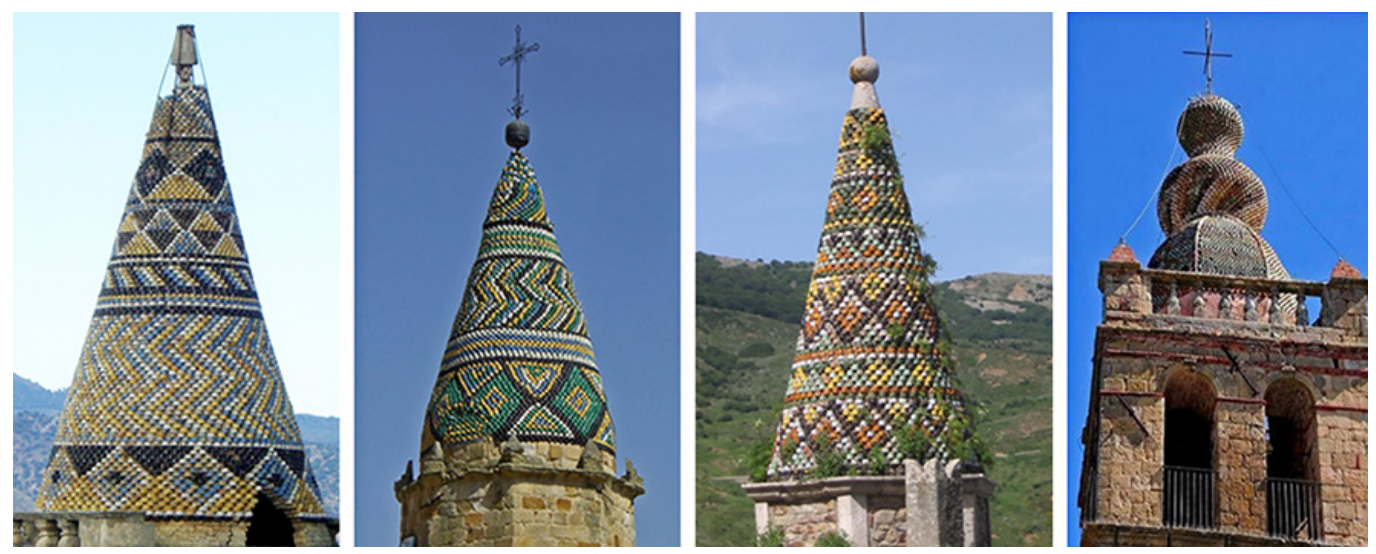


\section{Introduzione}

II rivestimento di superfici architettoniche a curvatura variabile è da sempre considerata una sfida per i costruttori di tutte le epoche. La scelta del tipo di finitura (continua/discontinua, a elementi di piccole/grandi dimensioni, realizzata con uno strato continuo di intonaco ovvero a lastre/elementi lapidei, lignei o metallici) e del sistema di posa in opera risultano di fondamentale importanza sia per la resa estetica che per un'efficace protezione delle strutture rivestite. In ambito architettonico, nella realizzazione di un paramento murario, se da una parte l'uso di elementi di dimensioni ridotte conferisce alla superficie geometrica complessa una maggiore continuità nel caso in cui si utilizzano elementi piani (questo è ad esempio il caso delle tessere dei mosaici), dall'altro incrementa il numero di giunti presenti e di conseguenza il rischio di eventuali infiltrazioni e conseguenti degradi [Ragona 1986].

Una soluzione originale e di particolare interesse, in grado di coniugare l'istanza estetica con quella strutturale e di durabilità è rappresentata dall'uso di particolari e originali mattoni cuneiformi in laterizio maiolicato diffusi in Sicilia a partire dal XVI secolo per la realizzazione di cuspidi e cupole. Questa tecnica, con chiari riferimenti alla cultura architettonica mediorientale, trova in Sicilia una diffusione e una varietà non riscontrabile in altre aree geografiche [Fatta, Vinci 2010; Fiorilla 1989].

La ricerca sistematica intrapresa, attraverso un'indagine multidisciplinare, ha permesso di rilevare e catalogare gli esempi più significativi riconosciuti e censiti in Sicilia, analizzandone i principali centri di produzione e diffusione [Fatta, Vinci 2008; Reginella 2004].

Le geometrie delle cuspidi e delle cupole realizzate con questa tecnica e riscontrate più di frequente possono classificarsi in funzione della sezione orizzontale e delle geometrie in alzato: ritroviamo conformazioni coniche (più o meno allungate), piramidali (a base quadrata, esagonale, ottagonale, con lati uguali o accoppiati simmetricamente, più o meno depresse), bulboidi (a curvatura semplice in pianta o in sezione verticale, ovvero a curvatura doppia), emisferiche (a estradosso continuo ovvero con sezione orizzontale mistilinea) [Di Paola et al. 2018] (fig. I).

Fig. I. Geometria delle cuspidi. Dall'alto a sinistra: cuspide piramidale (Caltagirone, CT), emisferica (Barrafranca, EN), bulboide (Lucca Sicula, AG), piramidale (Palagonia, CT), cuspidi coniche (Leonforte, EN: Gagliano Castelferrato, EN; Geraci Siculo, PA) cuspide plurilobata (San Mauro Castelverde, PA).
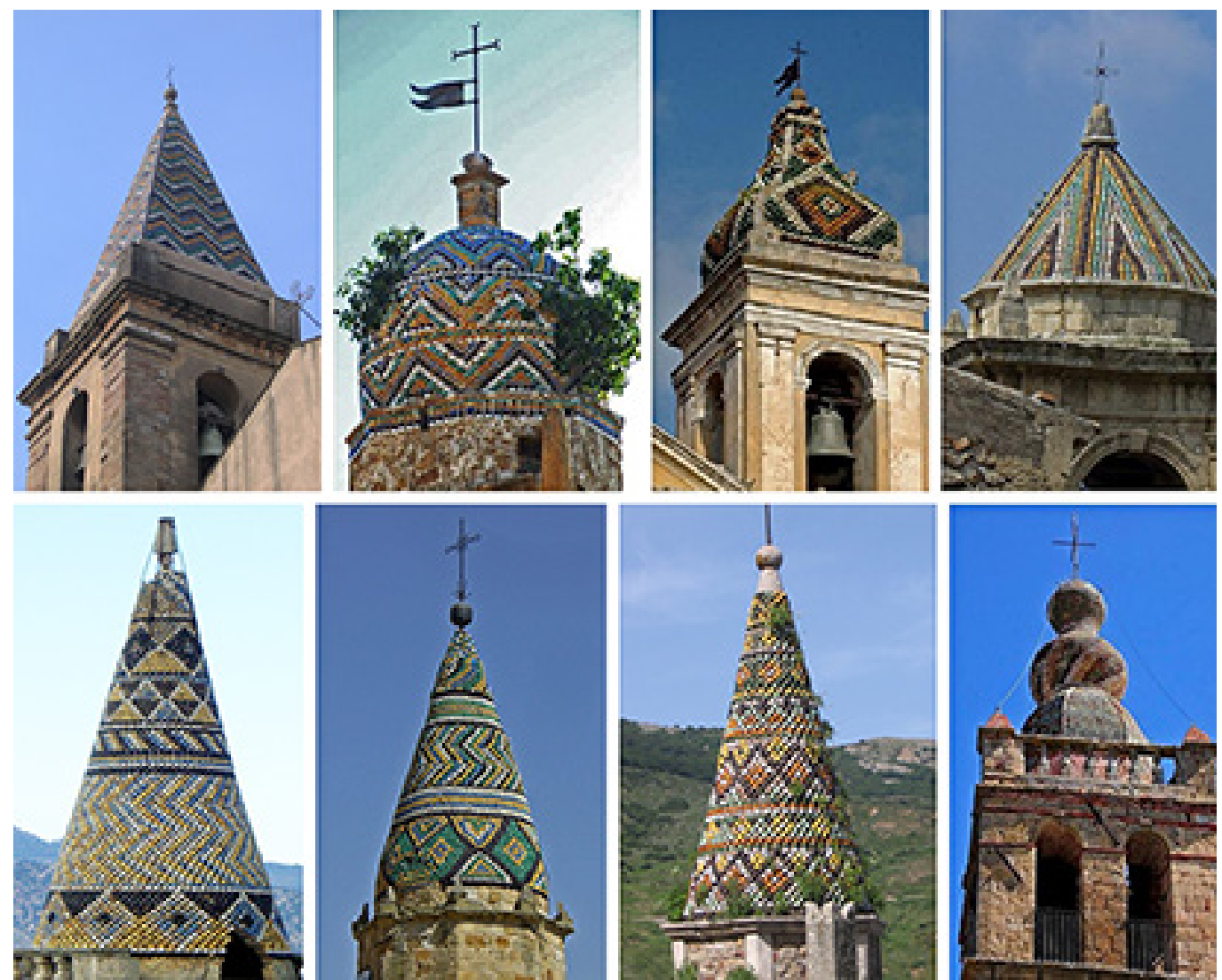


\section{II mattone cuneiforme maiolicato: geometria e forma}

I circa cento esempi siciliani studiati, e i molti altri casi di cui si ha testimonianza indiretta, dimostrano, a un'analisi più attenta, come l'uso dei mattoni cuneiformi in laterizio maiolicato per la costruzione di cuspidi e cupole risolva in modo economico ed efficace la notevole complessità di questi elementi architettonici che devono coniugare aspetti coloristici e decorativi, forme a curvatura complessa e originali soluzioni costruttive.

I mattoni cuneiformi costituiscono infatti, al contempo, rivestimento e struttura portante, consentendo una riduzione notevole dello spessore e del peso complessivo della struttura. I mattoni cuneiformi, che ritroviamo in quasi tutti i centri siciliani di produzione storica di ceramica (Caltagirone, Burgio, Sciacca, Collesano, Santo Stefano di Camastra ecc.), rappresentano per varietà delle forme un unicum. Questi elementi sono il risultato del lavoro di maestranze qualificate, artigiani in grado di ideare un ibrido tra un mattone comune e un manufatto dalla forma complessa.

Per aggregazione di pezzi identici, o con poche varianti morfologiche, si è in grado di generare veri e propri apparecchi murari di tipologia geometrico-costruttiva variabile, di cui costituiscono sia la struttura che la finitura policroma.

Un aspetto che certamente contribuì alla diffusione di questo sistema è la possibilità di rendere perfettamente impermeabile la parte esposta all'esterno dei mattoni cuneiformi, conferendo anche una varietà cromatica al paramento murario.

La ricerca condotta si è quindi basata sull'esame diretto di mattoni dalle forme inconsuete, raccolti presso collezionisti privati e nei musei specialistici, recuperati in seguito a crolli, rimasti (e dimenticati) all'interno dei campanili fin dalla prima costruzione, smontati nel corso dell'esecuzione di interventi di consolidamento e restauro.

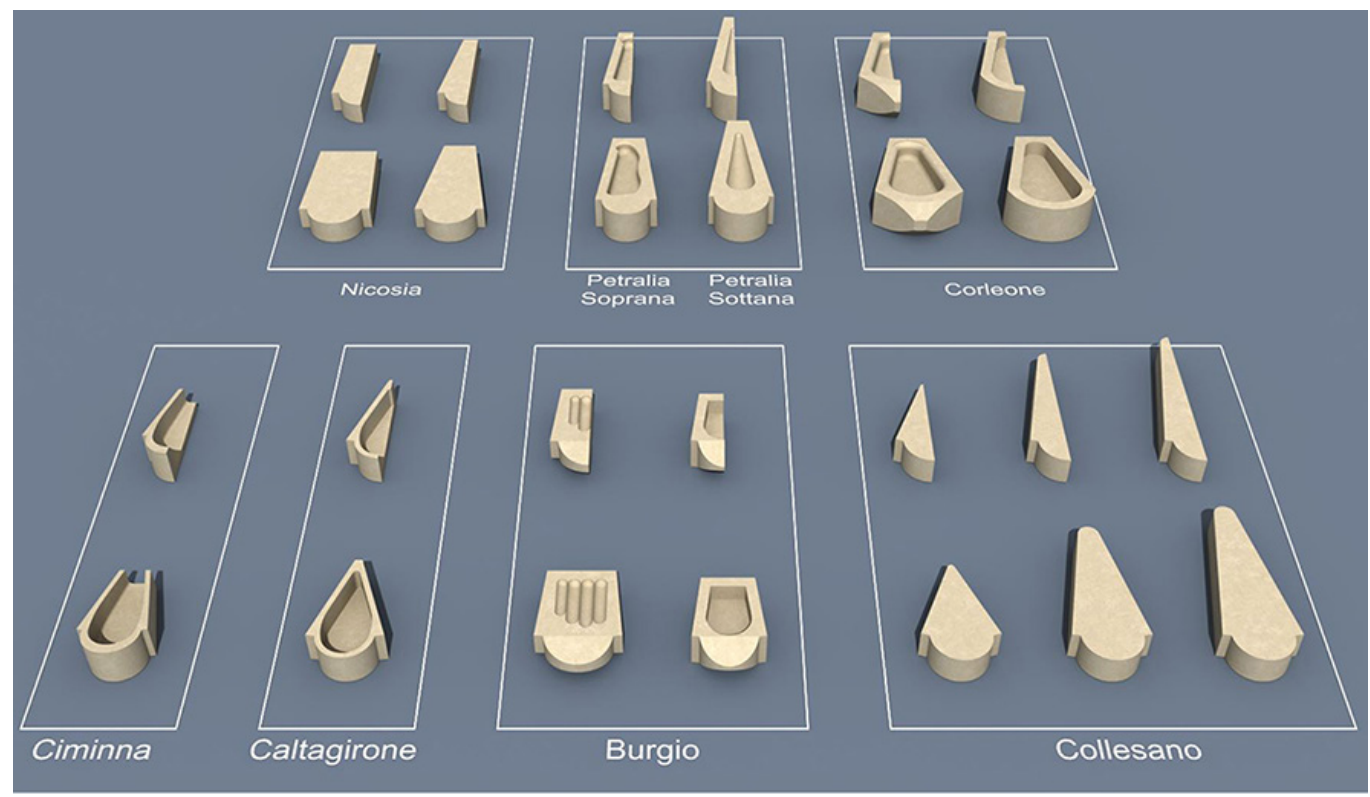

Fig. 2. Sicilia, cunei sagomati: in alto, ricostruzion tridimensionali di alcuni dei casi più frequenti; in basso, esempi di mattoni cuneiformi utilizzati nella stessa guglia con diversi angoli di rastremazione.
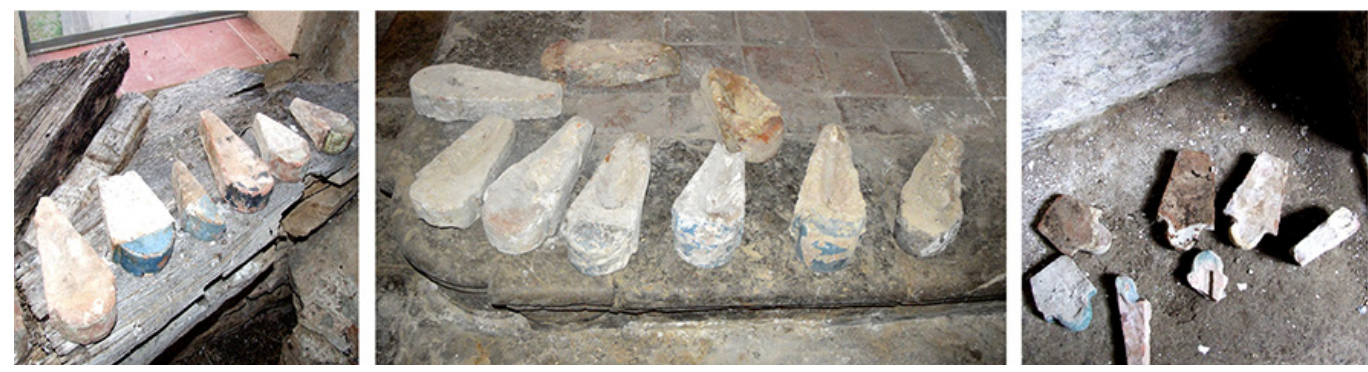
Nonostante l'elevato numero di varianti, i mattoni prodotti per la costruzione delle cuspidi maiolicate presentano delle caratteristiche comuni. Si tratta di elementi in cui la parte maiolicata è limitata all'estremità a vista; presentano spessore e lunghezza variabili, rispettivamente da tre a sei centimetri e da dodici a venticinque centimetri.

In generale, uno stesso elemento poteva essere utilizzato in applicazioni diverse con funzioni differenti (strutturale, collaborante, di rivestimento, semplicemente decorativo). La definizione di mattone 'a cuneo' deriva dalla presenza di una rastremazione, con angolo variabile, dei lati lunghi verticali (fig. 2).

II mattone presenta il più delle volte una concavità sulla faccia maggiore superiore, variabile nella profondità e nell'estensione a secondo della provenienza e del periodo di produzione. Sulla faccia opposta, spesso si notano anche solchi o buchi ciechi prodotti con appositi strumenti, ovvero con le stesse dita, per migliorare l'aderenza della malta. In molti casi la parte concava diventa talmente estesa da rendere minimo lo spessore delle pareti laterali del mattone (da ciò la definizione di 'burnie', cioè vasi), questo consentiva di aumentarne la leggerezza senza perdere in resistenza.

La faccia maiolicata dei mattoni che resta a vista presenta sagome diverse: punta diamantata più o meno pronunciata (torica, prismatica a spigolo smussato, curva ad andamento più o meno semplice) in quasi tutti i casi ricorrono dei dentelli laterali in sottosquadro, che consentivano la dissimulazione del giunto verticale e semplificavano le operazioni di stuccatura dei giunti stessi [I].

\section{Forma e struttura gemetrica}

Altra questione certamente complessa è la modalità di aggregazione dei cunei per la formazione di superfici murarie (a curvatura semplice, doppia o variabile) con motivi geometrici dati dalla differenza cromatica delle parti maiolicate.

Nel caso studio in esame l'esame della geometria del mattone cuneiforme, prevalentemente attraverso il rilievo e la lettura diretta, ha richiesto una serie di considerazioni concernenti la metodologia da adottare per discernere tra i molteplici aspetti che li caraterizzano (forma e dimensioni; tecnica costruttiva; apparecchiatura; lavorazione e loro finitura).

Concentrandosi sullimpianto tradizionale più diffuso della cuspide a superficie rigata conica, la metodologia impiegata ha permesso di determinare un daset di parametri generici appropriati in grado di generare un modello digitale interattivo (all'interno del plug-in e del noto software di modellazione NURBS Rhinoceros), costantemente modificabile in relazione ai dati iniziali e alle trasformazioni e operazioni a esso associate (fig. 3).

In una cuspide conica potevano essere utilizzate fino a quattro tipologie di cunei, identici nella conformazione esterna delle teste maiolicate, differenti per lunghezza totale e per angolo di rastremazione dei lati lunghi verticali, in considerazione della necessità di seguire la
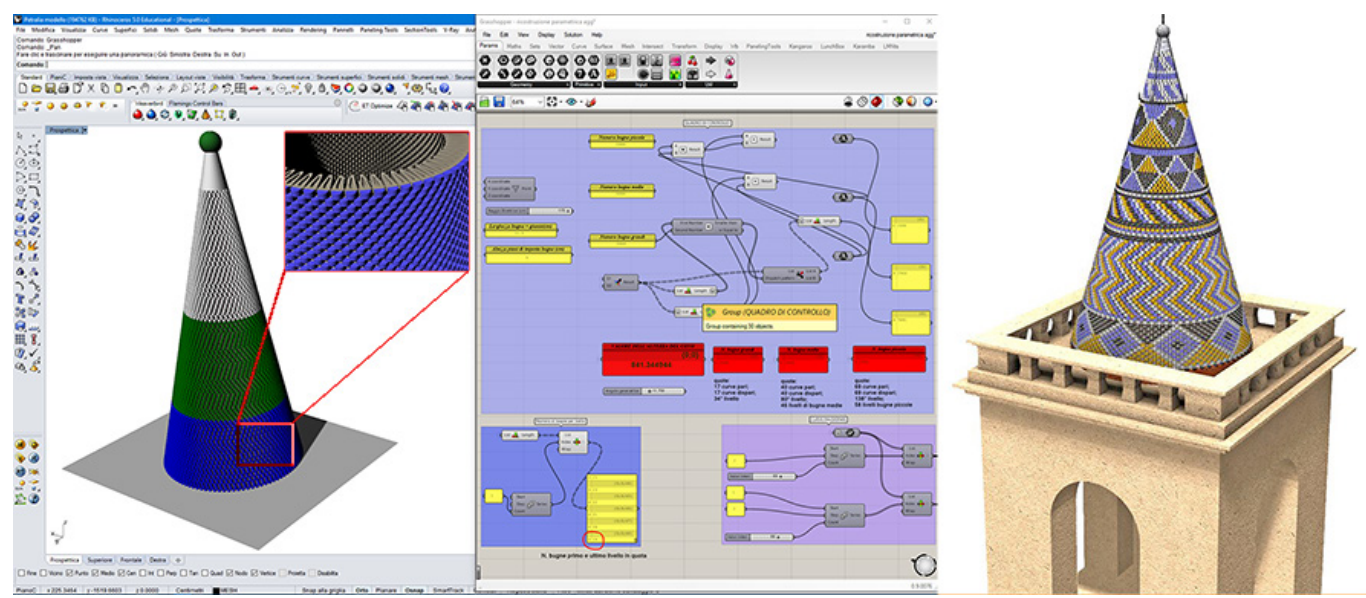
riduzione della circonferenza dei filari orizzontali dall'imposta fino al vertice della struttura. La superficie di involucro della cuspide è suddivisa in fasce orizzontali costituite da filari di cunei disposti sfalsati di mezzo modulo. II numero di cunei si mantiene costante in ogni rango, determinando così la necessità, dopo un fissato numero di livelli, di ricorrere all'assemblaggio di elementi di dimensione minore con un angolo di rastremazione crescente.

Ognuna delle suddette tipologie veniva adoperata per una serie (più o meno numerosa) di ranghi adattando, allinterno della serie stessa, lo spessore dei giunti verticali e il numero complessivo di mattoni per rango per tenere conto della variazione geometrica.

Dall'impostazione di alcuni dati iniziali di progetto (raggio della direttrice della cuspide; numero dei cunei richiesti per la fornitura suddividi per dimensione; altezza di ogni filare, larghezza del giunto di connessione) il processo di generazione della forma geometrica della cuspide è controllato influendo sui vari elementi-cunei e sulle loro interazioni che sottengono a regole impostate sotto forma di parametri. Quest'ultimi tengono conto: della corretta disposizione nello spazio dei mattoni; del numero complessivo di questi per ogni rango; della loro variazione geometrica (lunghezza e rastremazione angolare) in relazione alla riduzione della circonferenza dei filari orizzontali dall'imposta fino al vertice della struttura.

\section{Pattern geometrici e progettazione algoritmico-parametrica di nuove composizioni di tessitura muraria}

Sono numerosi gli esempi di architetture che vedono l'utilizzo del mattone in laterizio per la realizzazione di inediti apparecchi murari. Solo per citare alcuni maestri che hanno sperimentato nel $X X$ secolo un impiego innovativo del mattone, si ricordano: Frank Lyoyd Wright con i volumi continui e ondulati degli Uffici Johnson a Racine; Antoni Gaudí con
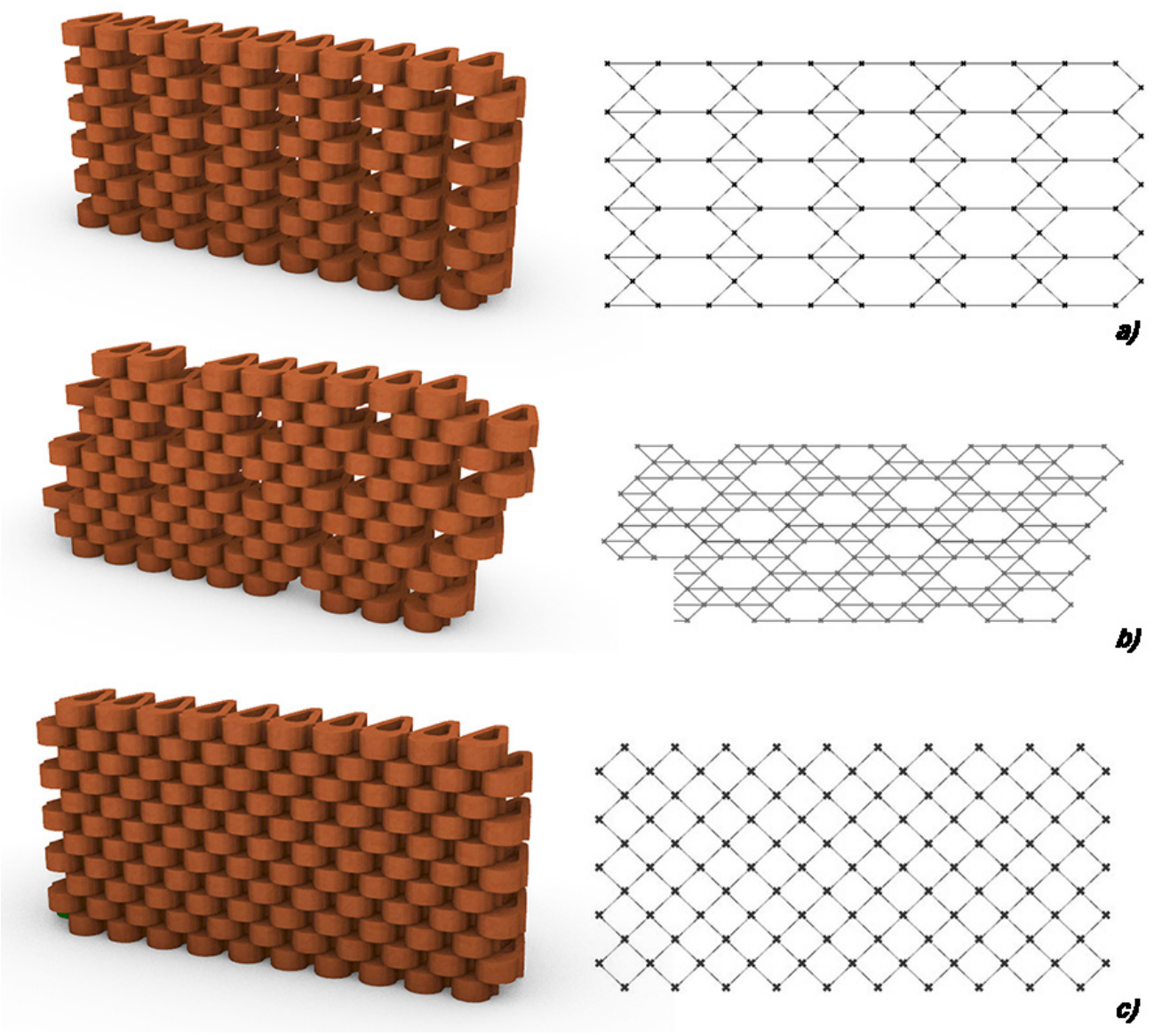
l'ingegnoso sistema della cripta di Santa Coloma di Cervellò; Hendrik Petrus Berlage con le sofisticate soluzioni d'angolo nella sala a cupola all'interno degli uffici della Höchster Farwerke a Francoforte; in epoca più recente le opere di Mario Botta [Mezzetti 2003].

In quest'ottica, in una rilettura contemporanea, che coniuga un componente di base della tradizione con tecniche di progettazione avanzate, i mattoni in laterizio cuneiformi potrebbero essere aggregati secondo grigliati compositivi flessibili e adattabili, posti in opera direttamente in cantiere o preassemblati all'intermo di pannelli modulari di grandi dimensioni [Gentry 20।3].

Il rigore nell'applicazione delle regole della geometria e i numerosi pattern generati dall'assemblaggio di questi elementi modulari restituiscono configurazioni plastiche di grande impatto formale.

Oggi, la progettazione algoritmico-parametrica e gli attuali strumenti digitali di creazione e di controllo di geometrie complesse sviluppate nello spazio, contribuiscono efficacemente a sperimentare nuovi tracciati tipologico-compositivi e nuove soluzioni tecnico-costruttive di paramenti murari. Con le logiche parametriche si è in grado di disegnare un modello tridimensionale di paramento murario, costituito da un grande numero di mattoni [Cavieres et al. $201 \mathrm{l}]$.

I paramenti murari in mattoni cuneiformi in laterizio potrebbero essere di tipologia differente in relazione al pattern geometrico impostato: autoportanti a faccia vista o di rivestimento superficiale. I primi verrebbero montati in opera a secco in cantiere e avrebbero funzione autoportante, mentre i secondi verrebbero incollati, assolvendo esclusivamente a una funzione estetica (figg. 4, 5).

In accordo con le proprietà geometrico-formali della superficie da realizzare, ogni componenete assumerà nello spazio digitale una posizione particolare, ruotata e traslata secondo angoli, direzioni e giaciture variabili dettate da specifiche regole imposte dal progettista.

Qualsiasi modifica dell'andamento della superficie, anche complessa a curvatura variabile, aggiornerà in tempo reale la disposizione di tutti gli elementi costitutivi nel rispetto della topologia della forma geometrica complessiva (curvature principali, direzioni normali in un determinato punto, cambi di giacitura) e delle reciproche relazioni semantiche all'interno di uno specifico dominio [Al-Haddad et al. 20 I0].

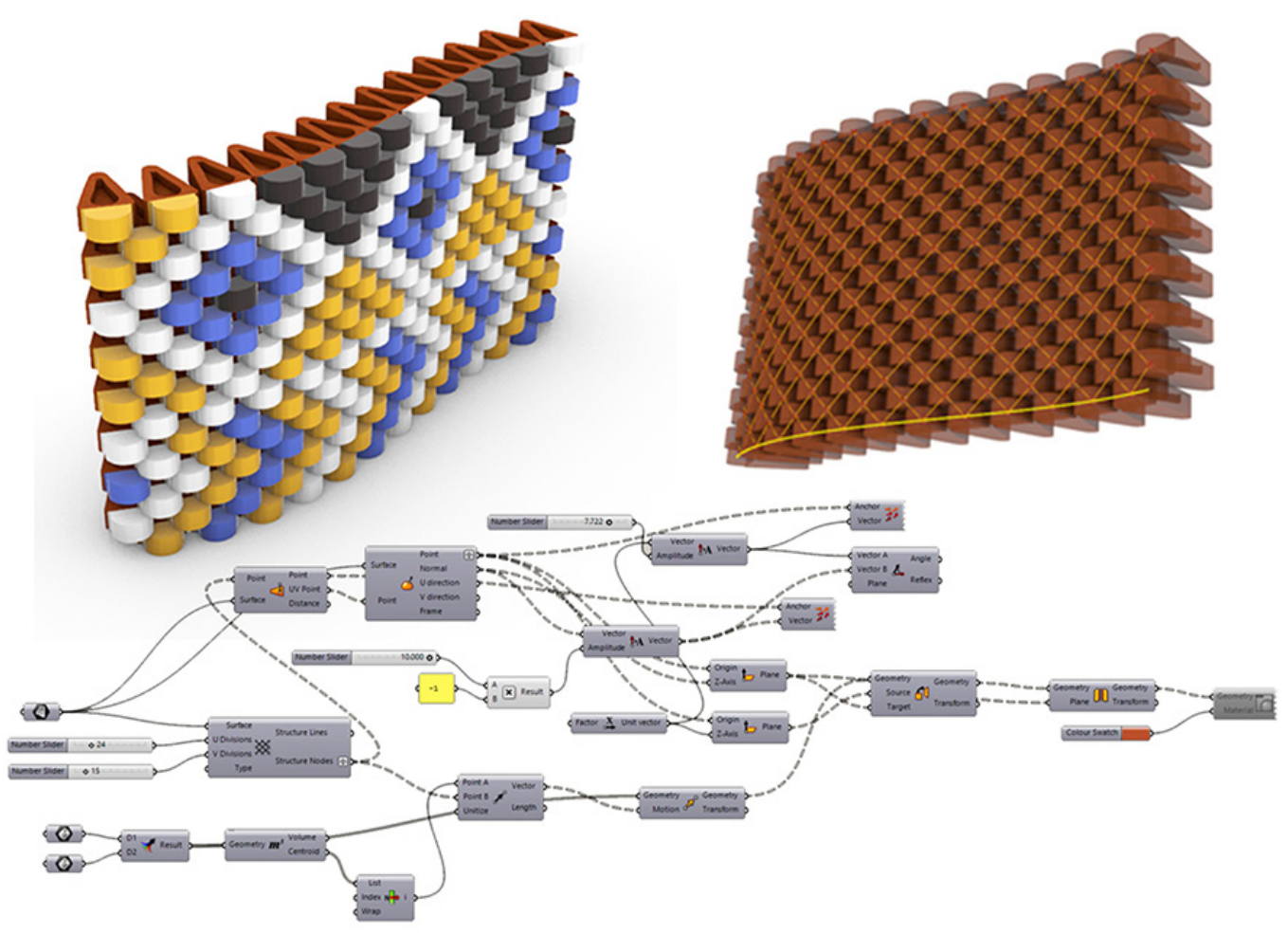


Fig. 6. Costruzione di sistemi a braccio robotizzato (Gramazio e Kohler dell'ETH dizürich) o con l'impiego di droni.
Fig. 7. Tre oggetti di design che reiterpretano la 'bugna' cuneiforme. Da sinistra verso destra: un centrotavola; un vasetto yogurt e un'alzatina porta frutta Martorana (progetti di Elisa Costa).
II progettista è così in grado di testare molteplici soluzioni che soddisfino parametri e vincoli impostati.

I software sviluppati con logiche parametriche, ad esempio, permettono di tradurre un'immagine in scala di grigi in una tessitura muraria, oppure colorare la testa del mattone seguendo pattern con motivi decorativi policromi preimpostati.

Ovviamente la messa in opera in cantiere presuppone un controllo metrico avanzato per garantire un rigore metodologico e una corretta apparecchiatura dell'intero sistema costruttivo. A tale scopo, le attuali sperimentazioni avviate impiegano bracci robotici e droni con una gestione automatica in remote [Latteur et al. 20 I5].

In questa direzione di sicuro interesse, nell'architettura contemporanea, si citano le opere degli architetti Gramazio e Kohler dell'ETH di Zürich, Switzerland [Gramazio, Kohle 2006] [2], oltre a quelle di Zwarts and Jansma Architects del 2014 (fig. 6) [3].

Questi esempi rappresentano audaci approcci in grado di sfruttare efficacemente le potenzialità degli attuali strumenti di progettazione algortmico-procedurale con l'impiego di tecnologie robotizzate di fabbricazione e produzione digitale.
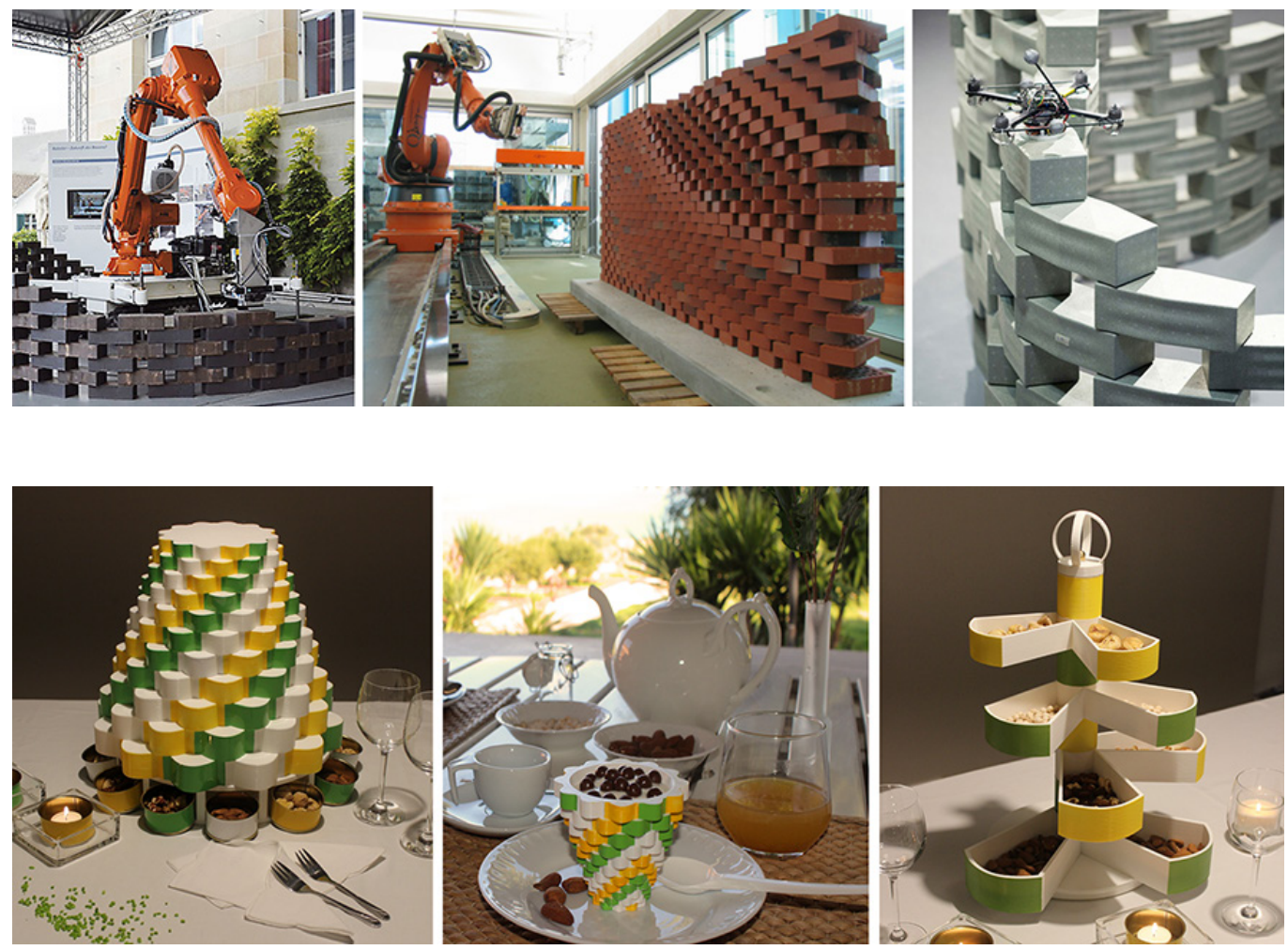

\section{Conclusioni}

La tecnica di rappresentazione impiegata e il procedimento parametrico adottato per la generazione del modello costituiscono un valido strumento di indagine, di analisi e di controllo in grado di esplorare in un'unica definizione algoritmica la complessa articolazione spaziale del sistema nelle diverse tipologie geometriche sperimentate.

L'algoritmo generativo definito secondo una logica associativa descrive e controlla le relazioni geometriche degli elementi che compongono la struttura generale, permettendo l'esplorazione di molteplici configurazioni e modificando in tempo reale le caratteristiche geometriche di ogni singolo componente.

L'implementazione degli strumenti digitali computazionali, in grado di creare pattern geometrici variabili attraverso la modifica di parametri, può innovare soluzioni tecnico-costruttive per un efficace impiego del mattone cuneiforme nell'architettura contemporanea. 
Questo approccio parametrico ha, inoltre, delle potenzialità che risiedono nella multi-scalarità del metodo progettuale, potenzialità già parzialmente indagate attraverso un'esperienza laboratoriale interdisciplinare in Disegno Industriale. Ispirandosi alle "bugne" cuneiformi, si è reinterpretato l'impiego in accessori per la tavola, progettando oggetti di design innovati e versatili [4]. Di seguito in figura 7 si riportano alcuni prototipi stampati con tecniche di prototipazione rapida 3D.

\section{Note}

[I] Un'analisi attenta consente inoltre di apprezzare l'ingegnosità di alcune soluzioni costruttive e l'inaspettata raffinatezza e cura degli accorgimenti tecnici (i giunti orizzontali sono quasi invisibili e quelli verticali sono accuratamente stilati; la conformazione dei singoli cunei è funzionale all'osservazione dal basso) che hanno fatto in modo che questi elementi avessero una sufficiente durabilità e qualità estetica.

[2] Un team dell'Istituto diTecnologia in Architettura del Politecnico di Zurigo ha sviluppato e testato con successo un sistema robotico che consente all'uomo di interagire con i robot nei cantieri, sfruttando efficacemente i vantaggi delle capacità sia umane che meccaniche.

[3] Si veda: <https://www.zja.nl/en/page/23 I I/parametric-design-for-brick-surfaces> sito consultato il I 5/02/2020.

[4] Durante il Laboratorio di Disegno Industriale del Corso di Studi in Disegno Industriale dell'Università di Palermo, A.A. $2017 / 2018$, tenuto dalla prof.ssa Anna Catania in collaborazione con gli autori, è stata organizzata una mostra itinerante. II percorso espositivo tra tradizione e innovazione presenta nuovi manufatti, prototipi di Design ispirati alla tipologia delle cuspidi maiolicate siciliane.

\section{Riferimenti bibliografici}

Al-Haddad Tristan et al. (2010). Representation + Fabrication: Connecting descriptions and artifacts in the digital age. Washington DC: Architectural Research Centers Consortium Washington DC.

Cavieres Andres, Gentry Russel, Al-Haddad Tristan (20I I). Knowledge-based parametric tools for concrete masonry walls: Conceptual design and preliminary structural analysis. In Automation in Construction, vol. 20, Issue 6, October 20 I I, pp. 71 6-728.

Di Paola Francesco, Fatta Giovanni, Vinci Calogero (2018). Wedge-shaped bricks spires and domes. Construction and decorative aspects. In Gambardella Carmine (a cura di). World Heritage and Knowledge. Representation | Restoration | Redesign | Resilience. Atti del XVI International Forum of Studies “'Le Vie dei Mercanti”, Napoli-Capri I4-I6 giugno 20 I 8. Napoli: La scuola di Pitagora, pp. 594-605.

Fatta Giovanni, Vinci Calogero (20I0). Cuspidi e cupole in mattoni maiolicati nell'architettura religiosa dell'area dei Sicani. In Marchese Antonino Giuseppe (a cura di). Atti del convegno Manierismo siciliano. Antonino Ferraro da Giuliana e l'età di Filippo II di Spagna. Giuliana (PA), I 8-20 ottobre 2009, vol. III, pp. I03- I 28. Palermo: I.L.A. Palma.

Fatta Giovanni,Vinci Calogero (2008). Laterizi maiolicati nella costruzione delle cuspidi in area siciliana. In Costruire in laterizio, 123, pp. 46-51.

Fiorilla Salvina (1986). Campanili con cuspidi maiolicate nella Sicilia sud-orientale. In Atti del Convegno Internazionale della Ceramica. Centro Ligure per la Storia della Ceramica Albisola, Centro Ligure per la Storia della Ceramica (Savona), XIX, pp. 275290.

Gentry Russel (20 I 3). Digital tools for masonry design and construction. In ARCC Architectural Research Conference. The Visibility of Research, Construction: Innovations in Materials and Construction, University of North Carolina at Charlotte March 27 - 30 , 2013 Editors Chris Jarrett, Kyoung-Hee Kim, Nick Senske, pp. 34-4I.

Gramazio Kohle (2006). Gantenbein Vineyard Facade. <http://www.gramaziokohler.com/web/e/projekte/52.html>

Latteur Pierre et al. (20I5). Drone-Based Additive Manufacturing of Architectural Structures. In Proceedings of the International Association for Shell and Spatial Structures (IASS), Symposium 20 I 5. Amsterdam 17-20 August 20 I5, Amsterdam, The Netherlands, pp. I- 12 .

Mezzetti Carlo (a cura di). (2003). Rilievo e analisi morfologico-descrittiva dei paramenti murari. Bologna: Edizioni Kappa.

Ragona Antonino (1986). La maiolica siciliana dalle origini all'Ottocento. Palermo: Sellerio Editore.

\section{Autori}

Francesco Di Paola, Università di Palermo, francesco.dipaola@unipa.it

Giovanni Fatta, Università di Palermo, giovanni.fatta@unipa.it

Calogero Vinci, Università di Palermo, calogero.vinci@unipa.it

Per citare questo capitolo: Di Paola francesco, Fatta Giovanni, Vinci Calogero (2020). II mattone cuneiforme maiolicato. Procedure algoritmico-parametriche digitali come strumento di indagine e progettazione: dall'architettura storica all'innovazione del design/TheWedge-Shaped Majolica Brick. Digital Algorythmic-Parametric Procedures to Investigate and Design: from Historical Architecture to Design Innovation. In Arena A., Arena M., Brandolino R. G., Colistra D., Ginex G., Mediati D., Nucifora S., Raffa P. (a cura di). Connettere. Un disegno per annodare e tessere. Atti del $42^{\circ}$ Convegno Internazionale dei Docenti delle Discipline della Rappresentazione/Connecting. Drawing for weaving relationships. Proceedings of the 42th International Conference of Representation Disciplines Teachers. Milano: FrancoAngeli, pp. 429-444. 


\title{
The Wedge-Shaped Majolica Brick. Digital Algorythmic-Parametric Procedures to Investigate and Design: from Historical Architecture to Design Innovation
}

\author{
Francesco Di Paola \\ Giovanni Fatta \\ Calogero Vinci
}

Abstract

The study focuses on the cuneiform in majolica brick that has been widespread in Sicily since the 16 th century for the construction of spires and domes. A unifying element that has constituted a particular identity contribution to the island's brick tradition; an original solution able to combine aesthetics with structural and durability. On the basis of more than a hundred examined cases, the different geometrical-formal peculiarities detected in relation to the characteristics of the shell are described. Some analyses and checks of the traditional geometrical composition patterns of the wall facade are reported. Through the definition of digital tools of algorithmic-parametric design, new configurations of masonry texture on surfaces with variable curvature are proposed for a contemporary re-proposition of the building component with last-generation materials and techniques.
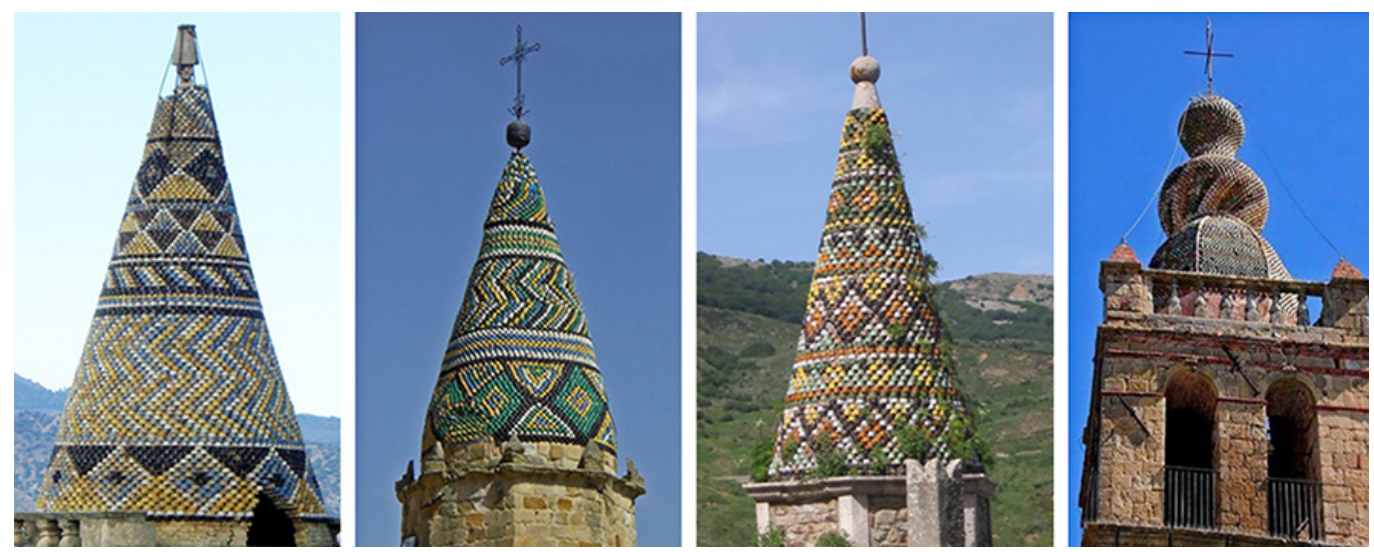


\section{Introduction}

The tiling of architectural surfaces with variable curvature has always been considered a challenge for architects of all ages. The choice of the coating type (continuous/discontinuous, with small/large components, made with a curtain layer of plaster or with stone, wood or metal slabs/elements) and of the installation system are essential in terms of aesthetic performance and effective protection of the clad structures.

In the architectural field, in the construction of a masonry face, if on one side the use of small elements gives the complex geometric surface greater continuity when using flat elements (this is for example the case of mosaic tiles), on the other side it increases the number of joints present and consequently the risk of infiltration and consequent degradation [Ragona 1986].

An original and particularly interesting solution, able to combine aesthetics with structural and durability is represented by the use of unique and distinctive cuneiform bricks in majolica bricks, widespread in Sicily since the 16 th century for the construction of spires and domes. This technique, with clear references to Middle Eastern architectural culture, finds in Sicily a diffusion and variety that is not found in other geographical areas [Fatta, Vinci 20 I0; Fiorilla 1989].

The systematic research carried out, through a multidisciplinary investigation, has made it possible to detect and catalogue the most significant examples recognized and surveyed in Sicily, analyzing the main centres of production and diffusion [Fatta,Vinci 2008; Reginella 2004]. The geometries of cusps and domes made with this technique and most frequently found can be classified according to the horizontal section and the geometries in elevation. It is possible to identify: conical conformations (more or less elongated); pyramidal (square, hexagonal, octagonal, with equal or symmetrically coupled sides, more or less depressed); bulboidal (with simple curvature in plan or in vertical section, or double curvature); hemispherical (with continuous extrados or with horizontal mixed section) [Di Paola et al. 20। 8] (fig. I).

Fig. I. Geometry of spires. From top left: pyramidal ones (Caltagirone, CT), hemispherical ones (Barrafranca, EN), bulboid ones (Lucca Sicula, AG), pyramidal ones (Palagonia, CT), conical ones Leonforte, EN; Gagliano Castelferrato, EN: Gerac Siculo, PA), multilobed ones (San Mauro Castelverde, PA).
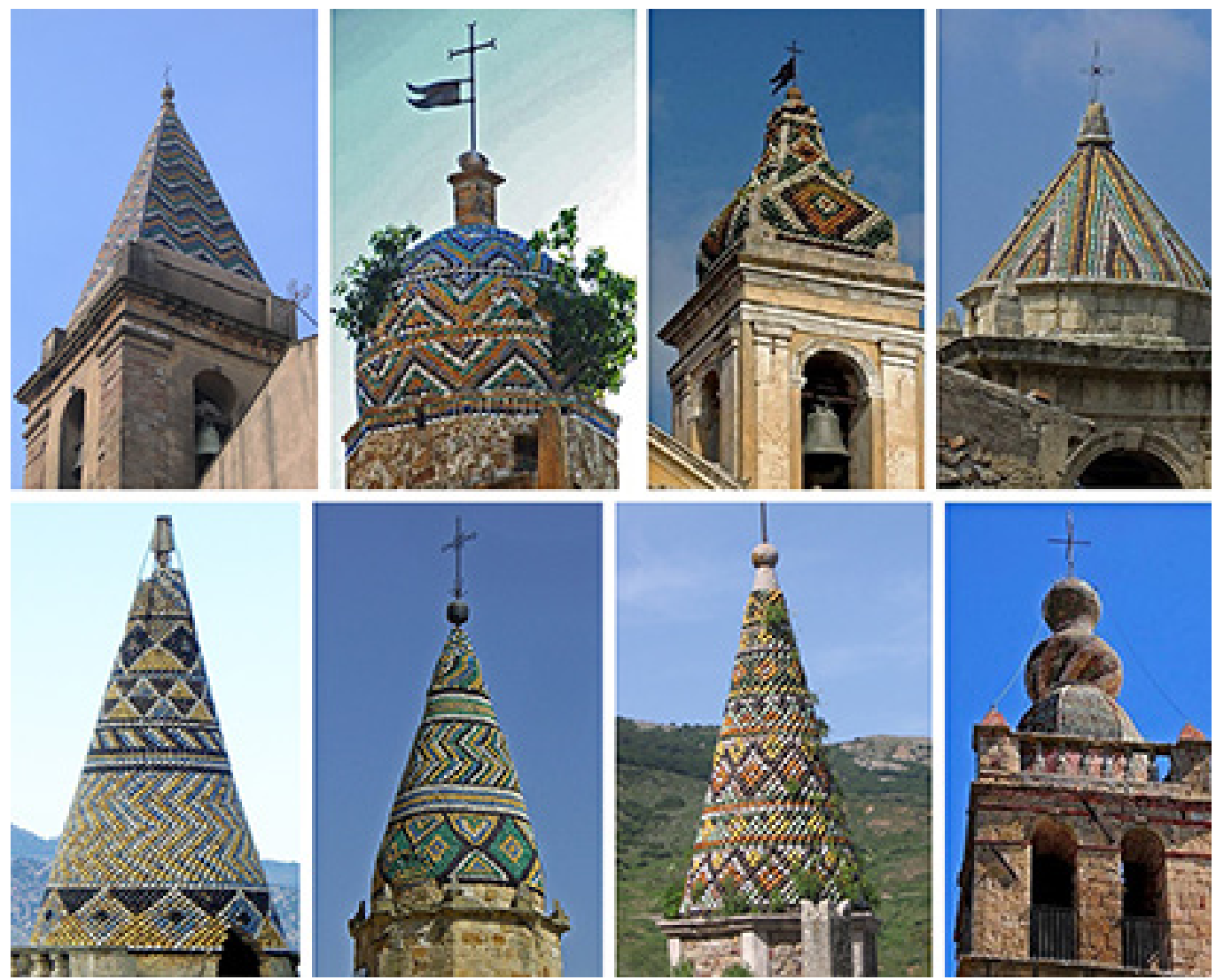


\section{The wedge-shaped majolica brick: geometry and shape}

The hundreds Sicilian examined examples, and the many other cases of which there is indirect testimony, demonstrate, on deeper analysis, how the use of cuneiform bricks provides an economic and effective solution to the considerable complexity of these architectural components. Indeed, It combine coloristic and decorative aspects, complex curved shapes and original constructive solutions.

The wedge-shaped bricks constitute both wall tiling and load-bearing structure, allowing a considerable reduction in thickness and overall weight of the structure.

These bricks, that can be found in almost all the Sicilian centres of historical ceramic production (Caltagirone, Burgio, Sciacca, Collesano, Santo Stefano di Camastra etc.), represent a unicum for shape variety. These elements are the result of the work of qualified masters and artisans able to create a hybrid between a common brick and an artefact with a complex shape.

By joining identical pieces, or with few morphological variants, it is possible to generate real masonry structures of variable geometrical-constructive type, of that they constitute both the structure and the polychrome finish.

One aspect that certainly contributed to the diffusion of this system is the possibility of making the exposed part of the cuneiform bricks perfectly waterproof, also giving a chromatic variety to the wall face.

The research conducted was based on direct examination of bricks of unusual shapes, from private collectors and specialist museums, recovered after collapses, left (and forgotten) inside the bell towers since the first construction, dismantled during consolidation and restoration work.

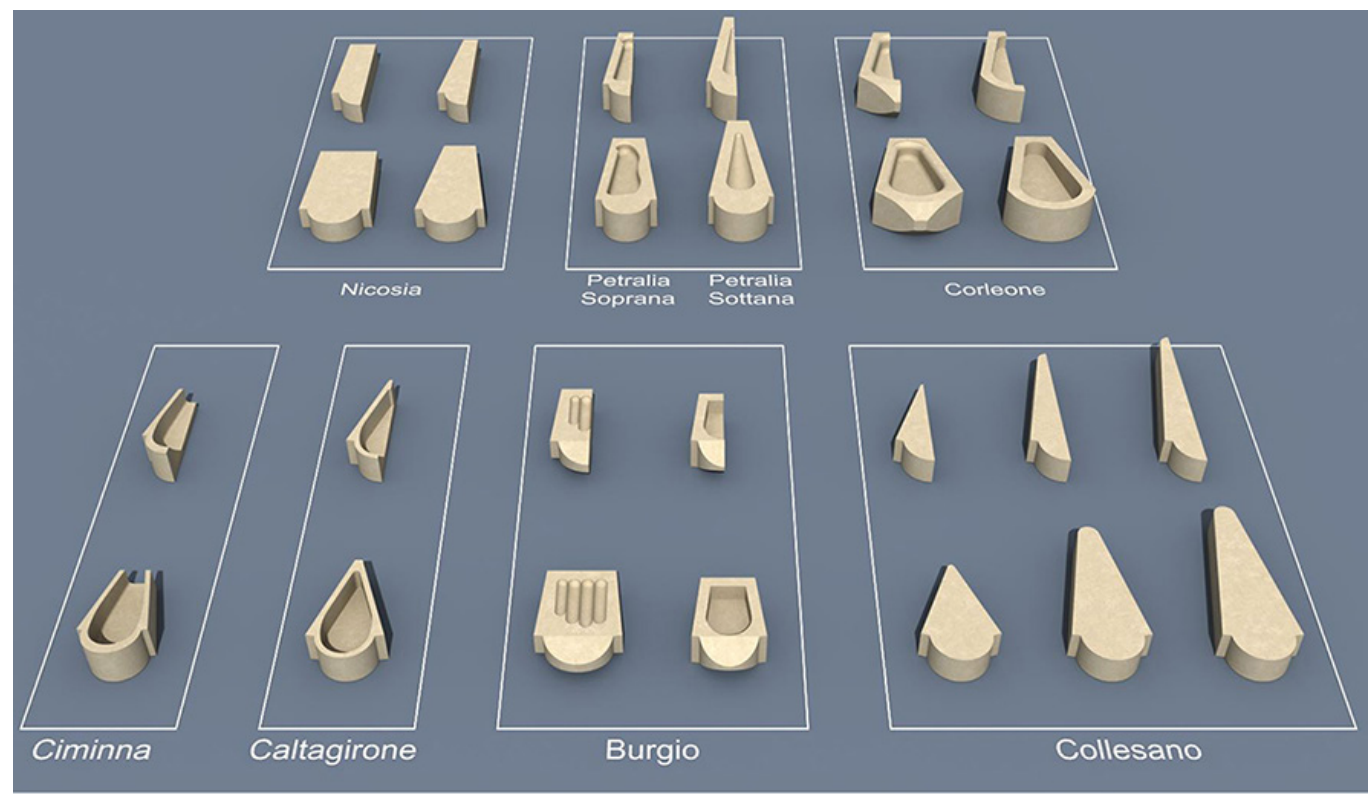

Fig. 2. Sicily, shaped wedges: up, three-dimensional reconstructions of some of the most frequent cases; down, examples of wedge-shaped bricks used in the same spire with different tapering angles.
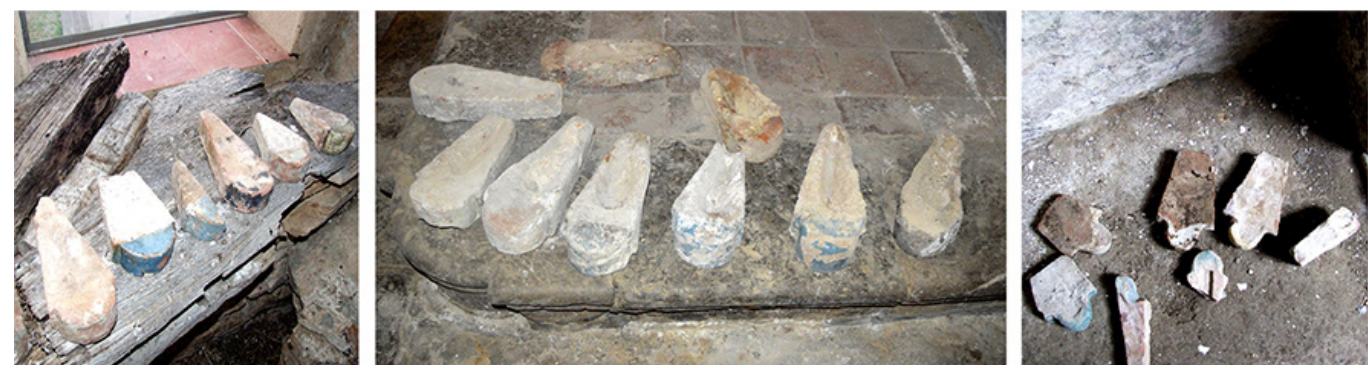
Despite the large number of variations, the bricks produced for the construction of the majolica cusps have some common characteristics. The majolica part is limited to the visible side, the thickness and length are variable, respectively from three to six centimetres and from twelve to twenty-five centimetres.

In general, the same component could be used in different applications with different functions (structural, collaborative, tiling). The definition of 'wedge-shaped' brick derives from the presence of a tapering, with variable angle, of the long vertical sides (fig. 2).

Most of the time the brick has a concavity on the upper side, varying in depth and extension depending on the origin and period of production. On the opposite face, there are often also grooves or blind holes produced with special tools, or with the fingers, to improve the mortar's adherence.

In many cases, the concave part becomes so large that the thickness of the side walls of the brick is minimal (hence the definition of burnie, or vases), this allowed to increase its lightness without losing strength.

The majolica face of the bricks that remains visible has different shapes: a more or less pronounced diamond point (toric, prismatic with a bevelled edge, more or less simple curve). In almost all cases there are side pins in the undercuts, which allowed the concealment of the vertical joint and simplified the grouting operations of the joints themselves [I].

\section{Shape and geometric structure}

Another issue that is certainly complex is the method of aggregating wedges for the formation of masonry surfaces (simple, double or variable curvature typology) with geometric patterns given by the chromatic difference of the majolica parts.

In the case study in question, the examination of the geometry of the wedge-shaped brick, mainly through surveying and direct reading, required a series of considerations regarding the methodology to be adopted to discern the multiple aspects that characterize them (shape and dimensions; construction technique).

Focusing on the most widespread traditional conical grooved-surface cusp, the methodology used made it possible to determine a dataset of appropriate generic parameters. These data allow to generate an interactive digital model (within the plug-in Grasshopper and the well-known modeling software NURBS Rhinoceros), constantly modifiable in relation to the initial data and the transformations and operations associated with it (fig. 3).

Up to four types of wedges could be used in a conical cusp, identical in the external conformation of the majolica heads, different in total length and tapering angle of the long vertical sides. Tapering is necessary as a consequence of the reduction of the circumferences of the horizontal rows, from the shutter to the top of the structure.

The enveloping surface of the spire is divided into horizontal layers consisting of rows of wedges arranged offset by half a module.

Fig. 3. Parametric procedure adopted for the reproduction of the model of the spire of the church of Santo Stefano in Leonforte (EN).
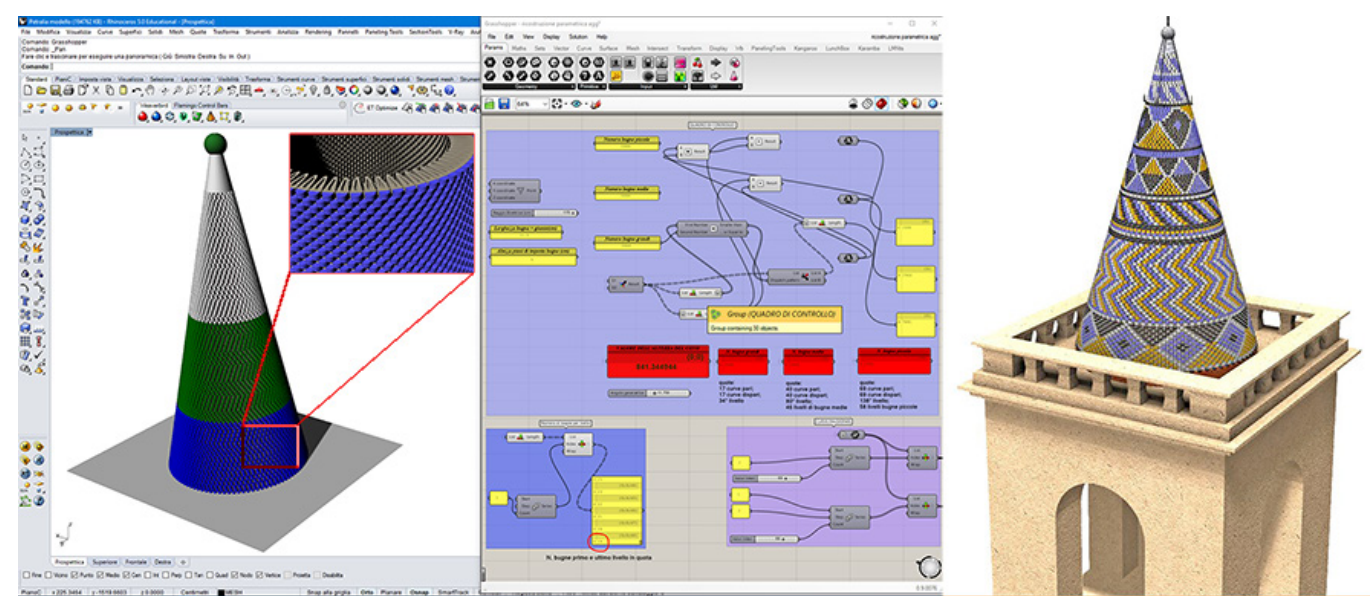
The number of wedges remains constant in each row, thus determining the requirement, after a fixed number of levels, to use the assembly of smaller elements with an increasing tapering angle.

Each of the above mentioned types was used for a series (more or less numerous) of rows adapting, within the series itself, the thickness of the vertical joints and the total number of bricks per row, to take into consideration the geometric variation.

From the setting of some initial design data (radius of the cusp direction; height of each row, width of the connection joint) the process of generating the geometric shape of the cusp is controlled by influencing the various wedge-elements and their interactions, underlying rules set in the form of parameters.

The latter are based on: the correct spatial arrangement of the bricks; the total number of bricks for each row; their geometrical variation (length and angular tapering) in relation to the reduction of the circumference of the horizontal rows from the set to the vertex of the structure.

\section{Algorithmic-parametric design of new wall geometric texture patterns}

There are numerous examples of architecture that show the use of brick for the construction of original masonry structures.

Just to mention some of the masters who experimented with an innovative use of brick in the 20th century: Frank Lyoyd Wright with the continuous, undulating volumes of the Johnson Offices in Racine; Antoni Gaudí with the ingenious system of the Crypt of Santa Coloma in Cervellò; Hendrik Petrus Berlage with the sophisticated corner solutions in the domed hall inside the Offices of Höchster Farwerke in Frankfurt; more recently the works of Mario Botta [Mezzetti 2003].
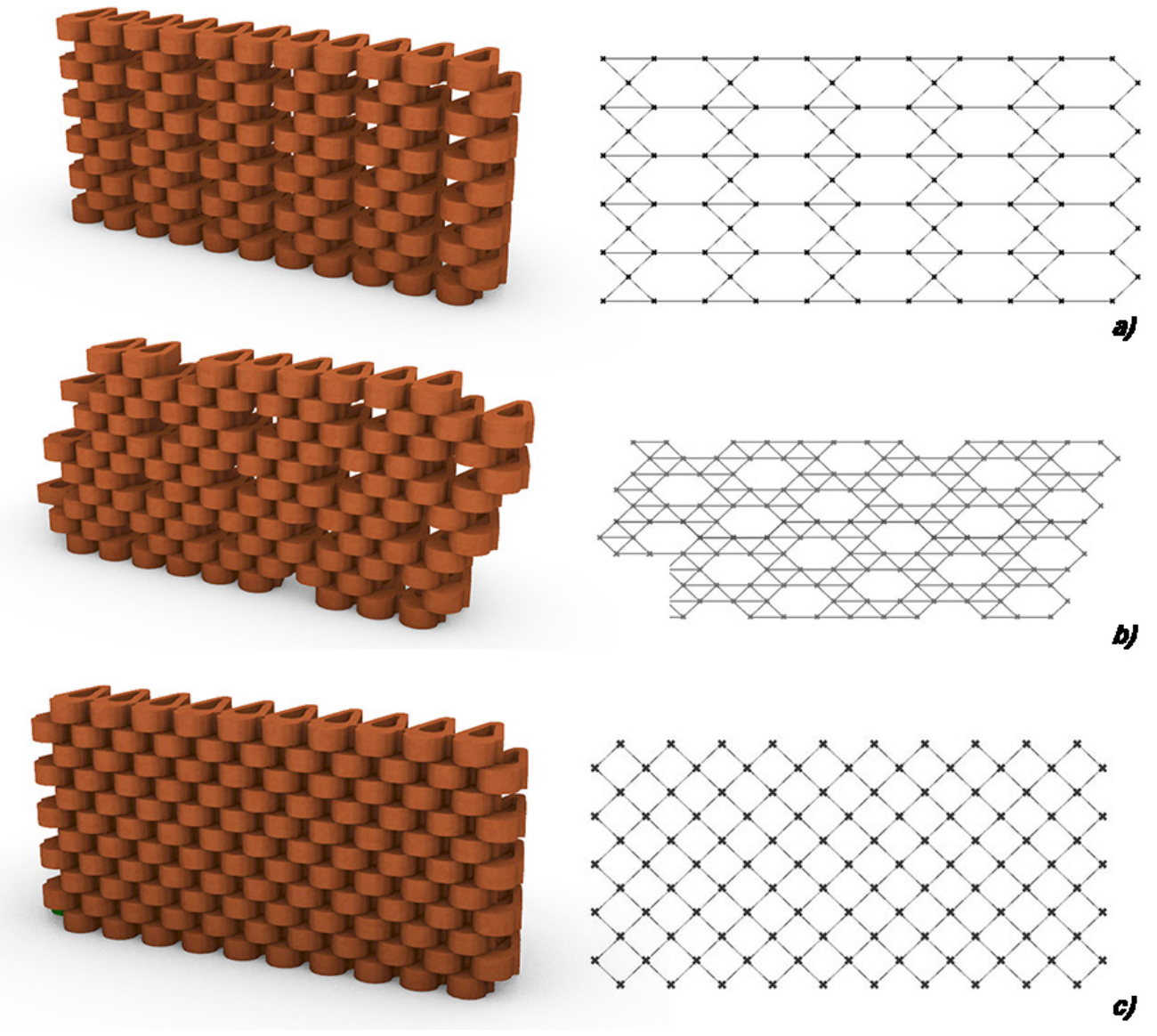
From this point of view, in a contemporary reinterpretation, combining a basic component of tradition with advanced design techniques, the wedge-shaped bricks could be aggregated according to flexible and adaptable compositional grids, installed directly on site or pre-assembled inside large modular panels [Gentry 20I3].

The rigour in the application of the geometry rules and the numerous patterns generated by the assembly of these modular components return plastic configurations of great formal impact.

Nowadays, the algorithmic-parametric design and the actual digital tools for the creation and control of complex geometries developed in space, effectively contribute to experiment new typological-compositive pathways and new technical-constructive solutions of masonry walls.

With parametric logics it is possible to draw a three-dimensional model of a masonry face, consisting of a large number of bricks [Cavieres et al. 20l I].

The masonry faces made of wedge-shaped bricks could be of different typology in relation to the set geometric pattern: self-supporting face or surface coating. The first ones would be dry-assembled on site and would have a load-bearing function, while the second ones would be fixed, performing exclusively an aesthetic function (figs. 4, 5).

According to the surface's geometrical-formal properties, each component will acquire a specific position in the digital space, rotated and shifted according to angles, directions and variable positions set by specific rules fixed by the designer.

Any change in the surface shape, even complex ones with variable curvature, will update in real time the configuration of all the constituent components according to the topology of the whole geometric shape (main curvatures, normal directions at a defined point, changes of position) and the mutual semantic relations within a specific domain [Al-Haddad et al. 2010].

Therefore, the designer is able to test multiple solutions that respect set parameters and constraints.

The developed software with parametric logic, for example, allow to translate a grayscale image into a wall texture, or to colour the brick head following patterns with preset polychrome decorative patterns.

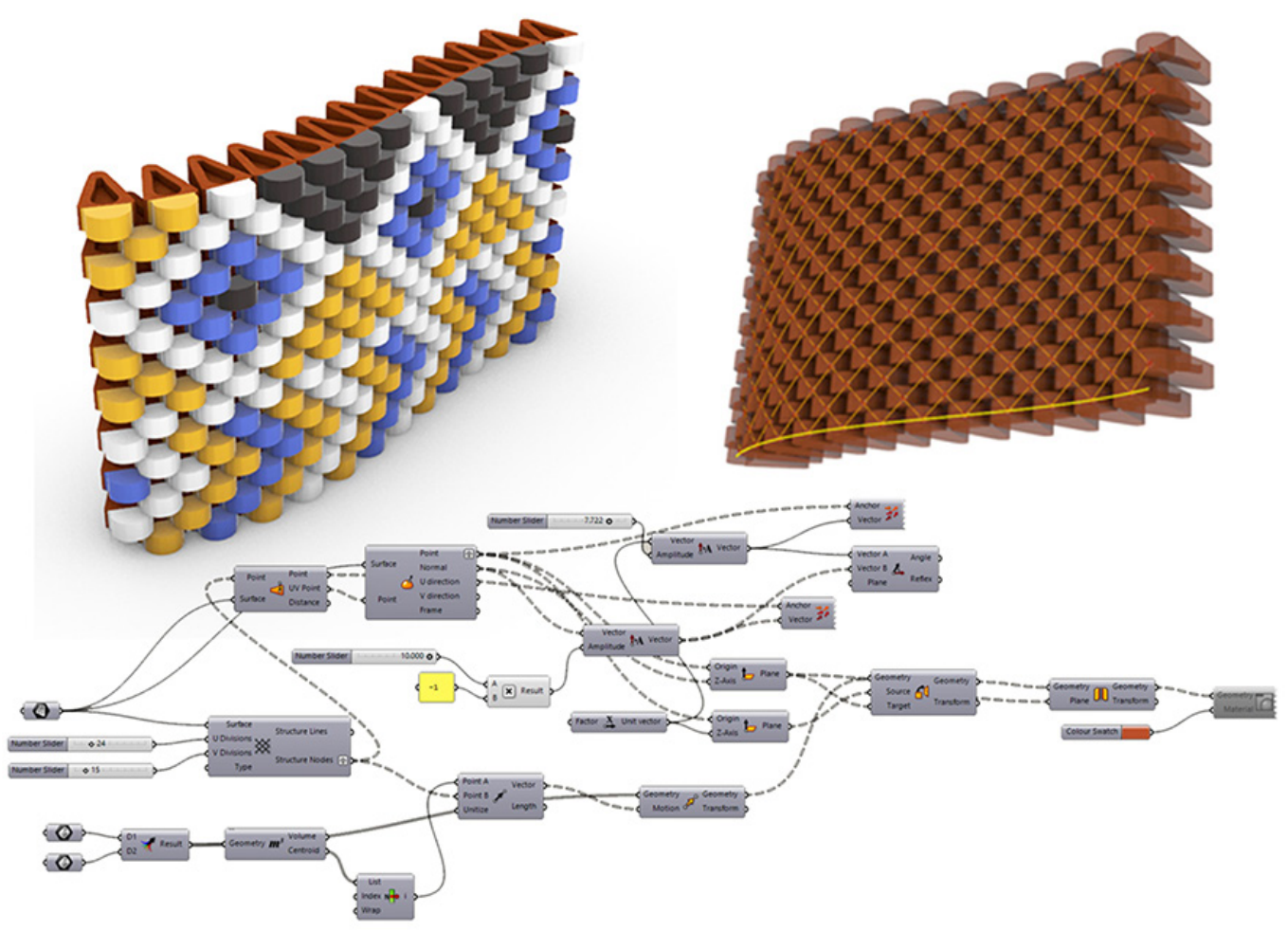


Fig. 6. Construction of masonry walls with robotic arm systems (Gramazio and Kohler from ETH Zürich) or with the use of drones.
Obviously, the installation on site requires advanced metric control to ensure methodological rigor and correct construction techniques.

To this aim, the current tests carried out employ robotic arms and drones with automatic remote control [Latteur et al. 2015].

In this direction of great interest, in contemporary architecture, the work by architects Gramazio and Kohler of the ETH in Zürich, Switzerland [Gramazio, Kohle 2006] [2], as well as that of Zwarts and Jansma Architects in 2014 are worth mentioning (fig. 6) [3].

These examples represent challenging approaches that effectively exploit the potential of contemporary algorithmic-procedural design tools with the use of robotic digital manufacturing and production technologies.
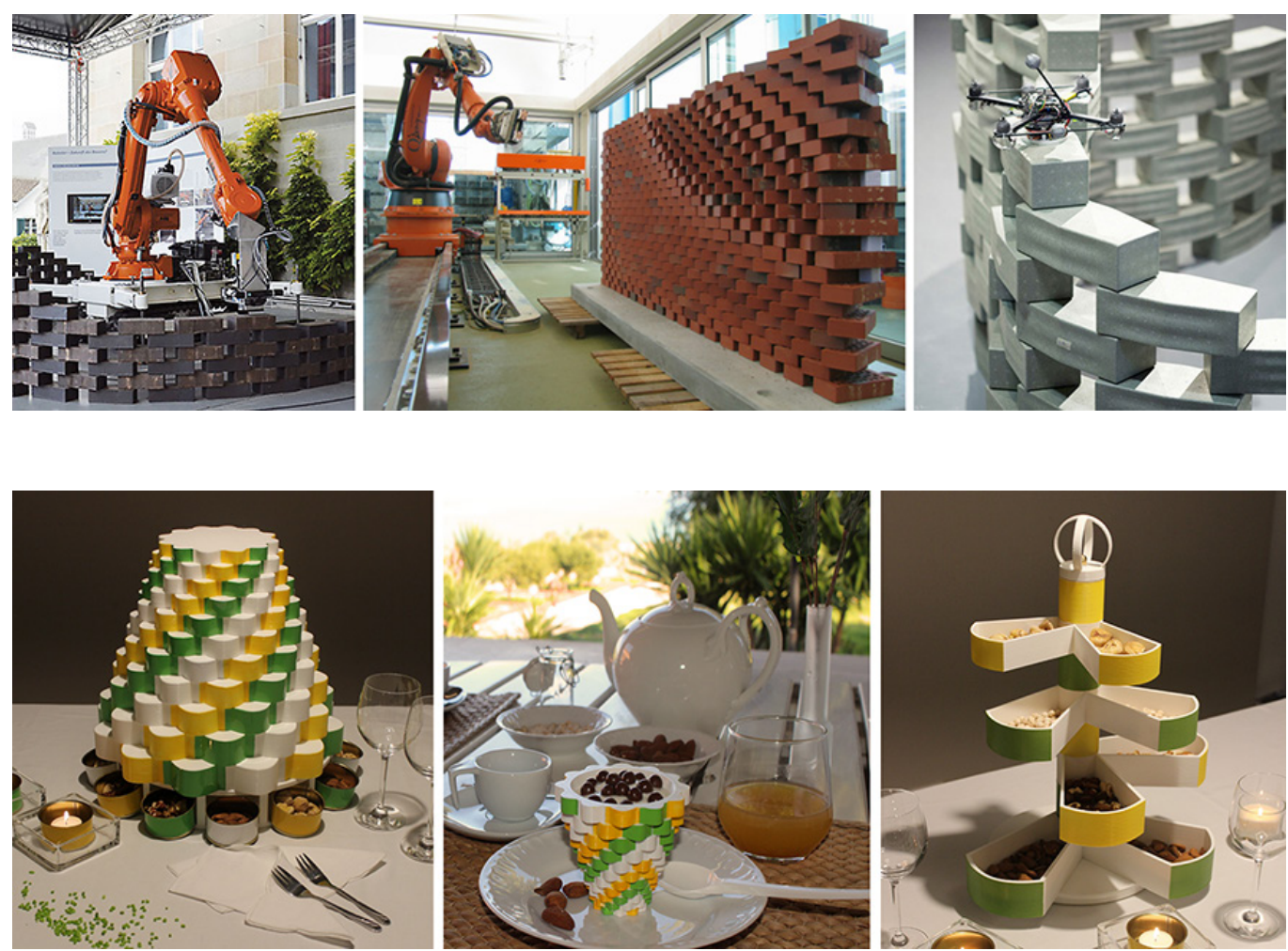

\section{Conclusion}

The representation technique used and the parametric procedure adopted for the generation of the model are a valuable tool for investigation, analysis and control. It is able to explore in a single algorithmic definition the complex spatial articulation of the system in the different geometric typologies tested.

The generative algorithm defined according to an associative logic describes and controls the geometric relationships of the elements that make-up the general structure.

The method allows the exploration of multiple configurations and modifying in real time the geometric characteristics of each single component.

The implementation of computational digital tools, able to create variable geometric patterns through the modification of parameters, can innovate technical-constructive solutions for an effective use of wedge-shaped brick in contemporary architecture.

This parametric approach also has potential in the multi-scale design method. These potentialities have already been partially investigated through an interdisciplinary laboratory 
experience in Industrial Design. Inspired by the cuneiform 'bugne', the use of these artefacts has been reinterpreted, transforming them into accessories for the dining table. For this aim, innovative and versatile design objects have been designed [4].

Below figure 7 shows some prototypes printed with 3D rapid prototyping techniques.

\section{Notes}

[I] A careful analysis also allows to appreciate the cleverness of some constructive solutions and the unexpected refinement and care of the technical solutions (the horizontal joints are almost invisible and the vertical ones are carefully drawn; the conformation of the single wedges is functional to the observation from below) that made these components have a sufficient durability and aesthetic quality.

[2] A team from the Institute of Technology in Architecture at ETH Zurich has developed and successfully tested a robotic system that allows humans to interact with robots on construction sites, effectively exploiting the advantages of both human and mechanical capabilities.

[3] See: <https://www.zja.nl/en/page/23। I/parametric-design-for-brick-surfaces>.

[4] During the Laboratory of Industrial Design of the Course of Studies in Industrial Design at the University of Palermo, A.A $2017 / 2018$, held by Prof. Anna Catania in collaboration with the Authors, a itinerant exhibition was organized. The exhibition path between tradition and innovation presents new products, prototypes of Design inspired by the typology of Sicilian majolica spires.

\section{References}

Al-Haddad Tristan et al. (2010). Representation + Fabrication: Connecting descriptions and artifacts in the digital age. Washington DC: Architectural Research Centers Consortium Washington DC.

Cavieres Andres, Gentry Russel, Al-Haddad Tristan (20I I). Knowledge-based parametric tools for concrete masonry walls: Conceptual design and preliminary structural analysis. In Automation in Construction, vol. 20, Issue 6, October 201 I, pp. 71 6-728.

Di Paola Francesco, Fatta Giovanni, Vinci Calogero (2018). Wedge-shaped bricks spires and domes. Construction and decorative aspects. In Gambardella Carmine (a cura di). World Heritage and Knowledge. Representation | Restoration | Redesign | Resilience. Atti del XVI International Forum of Studies “Le Vie dei Mercanti”, Napoli-Capri 14-I6 giugno 20 I 8. Napoli: La scuola di Pitagora, pp. 594-605.

Fatta Giovanni, Vinci Calogero (20l0). Cuspidi e cupole in mattoni maiolicati nell'architettura religiosa dell'area dei Sicani. In Marchese Antonino Giuseppe (a cura di). Atti del convegno Manierismo siciliano. Antonino Ferraro da Giuliana e l'età di Filippo II di Spagna. Giuliana (PA), I 8-20 ottobre 2009, vol. III, pp. I03- I 28. Palermo: I.L.A. Palma.

Fatta Giovanni, Vinci Calogero (2008). Laterizi maiolicati nella costruzione delle cuspidi in area siciliana. In Costruire in laterizio, I23, pp. 46-5I.

Fiorilla Salvina (1986). Campanili con cuspidi maiolicate nella Sicilia sud-orientale. In Atti del Convegno Internazionale della Ceramica. Centro Ligure per la Storia della Ceramica Albisola, Centro Ligure per la Storia della Ceramica (Savona), XIX, pp. 275290.

Gentry Russel (20 I3). Digital tools for masonry design and construction. In ARCC Architectural Research Conference. The Visibility of Research, Construction: Innovations in Materials and Construction, University of North Carolina at Charlotte March 27 - 30 2013 Editors Chris Jarrett, Kyoung-Hee Kim, Nick Senske, pp. 34-4I.

Gramazio Kohle (2006). Gantenbein Vineyard Facade. <http://www.gramaziokohler.com/web/e/projekte/52.html>

Latteur Pierre et al. (20I5). Drone-Based Additive Manufacturing of Architectural Structures. In Proceedings of the International Association for Shell and Spatial Structures (IASS), Symposium 20 15. Amsterdam 17-20 August 20 I5,Amsterdam, The Netherlands, pp. I- 12 .

Mezzetti Carlo (a cura di). (2003). Rilievo e analisi morfologico-descrittiva dei paramenti murari. Bologna: Edizioni Kappa.

Ragona Antonino (1986). La maiolica siciliana dalle origini all'Ottocento. Palermo: Sellerio Editore.

\section{Authors}

Francesco Di Paola, Università di Palermo, francesco.dipaola@unipa.it

Giovanni Fatta, Università di Palermo, giovanni.fatta@unipa.it

Calogero Vinci, Università di Palermo, calogero.vinci@unipa.it

To cite this chapter: Di Paola francesco, Fatta Giovanni,Vinci Calogero (2020). II mattone cuneiforme maiolicato. Procedure algoritmico-parametriche digitali come strumento di indagine e progettazione: dall'architettura storica all'innovazione del design/TheWedge-Shaped Majolica Brick. Digital Algorythmic-Parametric Procedures to Investigate and Design: from Historical Architecture to Design Innovation. In Arena A., Arena M., Brandolino R.G., Colistra D., Ginex G., Mediati D., Nucifora S., Raffa P. (a cura di). Connettere. Un disegno per annodare e tessere. Atti del $42^{\circ}$ Convegno Internazionale dei Docenti delle Discipline della Rappresentazione/Connecting. Drawing for weaving relationships. Proceedings of the 42th International Conference of Representation Disciplines Teachers. Milano: FrancoAngeli, pp. 429-444. 